DOI 10.18551/rjoas.2019-10.11

\title{
A STUDY ON INFLUENCING FACTORS OF SEAWEED FARMERS INCOME IN ROTE NDAO DISTRICT, INDONESIA
}

\author{
Sunadji \\ Department of Aquaculture, University of Nusa Cendana, Indonesia \\ Lusiana Evellin Dewi ${ }^{\star}$ \\ Department of Aquatic Resource Management, University of Brawijaya, Indonesia \\ *E-mail: evellinlusiana@ub.ac.id
}

\begin{abstract}
Seaweed is a superior commodity of Rote Ndao District. The island is located in Southern part of East Nusa Tenggara Province. The goal of this research is to analyze the factors that influence the seaweed farmers' income in Rote Ndao district. The data was collected in 2017. Following this, they were analyzed by using Pearson correlation and multiple linear regression analysis with a response and six predictor variables. The results of Pearson correlation analysis suggested that five predictors should be used. Then, on the results of assumption tests that are underlying multiple linear regressions revealed that regression model fulfills the requirement of normality, non-heteroscedasticity, and autocorrelation assumption. Th results showed that the non-multicollinearity assumption was violated. Therefore, two predictors need to be excluded, in order to get over it. Based on the multiple linear regression analysis finding it was suggested that the cost of rope, buoy, and wooden peg have positive effect on income. The rope's cost has significant influence while the others were not significant.
\end{abstract}

\section{KEY WORDS}

Regression, correlation, marine cultivation, production cost.

Indonesia is an archipelago country where its coastline is the second longest in the world. It also provided with great marine natural resources, in which one of them is seaweed. This fact is very beneficial for Indonesia as long as the resources are well managed. According to Radiarta et al (2016), one operational step that needs to be taken in relation to build independence of aquaculture in Indonesia is by developing seaweed cultivation. Indonesia's seaweed production accounted for $70.47 \%$ of the overall aquaculture production. Moreover, there was a positive trend of seaweed production in Indonesia between 2011 and 2015, where the average rate steadily increased a little over 19\% (BPS, 2015; KKP, 2015).

On the demand side, international market for dried seaweed is very high and tends to rise. The main importers of Indonesia's seaweed are China, Philippine, South Korea, and Vietnam with the market share $72.06 \%, 5.82 \%, 4,39 \%$, and $4.38 \%$ respectively. The number of seaweed export from 2011 to 2015 has increased with average rate $11,807.5$ tons/year (BPS, 2016).

The reason of seaweed's high demand in international market is because its use in industry and pharmacy is very broad. The advantages of seaweed cultivation are high labor absorption, easy and inexpensive cultivation technology, short planting period (45 days) and low-cost production (Parenrengi et al, 2006). Nevertheless, the potential of land for seaweed cultivation and seaweed's biological potential mentioned before does not necessarily mean that seaweed cultivating communities are economically prosperous. The fact shows that the community of seaweed farmers is still far compared to fish, shrimp and breeders. One thing that needs to be considered is to optimize the farmers' income by fixing the production cost (Chen and Duan, 2001). Production cost covers equipment for cultivation such as rope, wood, boat, tarpaulins, and waring net (Limi et al, 2018). 
East Nusa Tenggara is a province which located in southeast of Indonesia. It has high potency for seaweed cultivation. Soejarwo and Yusuf (2018) said that seaweed production in East Nusa Tenggara was the second largest in Indonesia after South Sulawesi, with Euchema cottoni as the main species. One of potential locations for seaweed cultivation in this province found in Rote Ndao district. The district is categorized as the outermost area in Indonesia and the prosperity of its people is low. Therefore, Indonesia government has prioritized this area for economic development, and seaweed cultivation has been chosen as the main sector for this (Andayani and Pamungkas, 2018). Since Rote Ndao district assigned as minapolitan region in 2010 , seaweed production in the area have been significantly increased. However, some improvements still needed to obtain better production results. Hence, the goal of this study is to analyze the factors affecting income of seaweed farmers in Rote Ndao district in terms of production cost.

\section{MATERIALS AND METHODS OF RESEARCH}

The data were collected during a survey in Rote Ndao district in 2017. There are several variables in this research, response and predictor variables. The response variable is income $(Y)$. Meanwhile, the predictors are farming area (X1), costs of rope (X2), buoy (X3), wooden peg (X4), ballast (X5), boat (X6) and seed (X7). All variables are measured in IDR. Before the data were being analyzed, they are transformed to natural logarithmic number. Data analysis was conducted by using Pearson correlation, assumption tests, and multiple linear regressions.

Pearson correlation analysis is used to identify the degree of association relationship between variables that denotes by correlation coefficient ( $r$ ). The formula to calculate correlation coefficient presented in equation (1) (Anderson et al, 2009).

$$
r_{X Y}=\frac{n \sum_{i=1}^{n} X_{i} Y_{i}-\sum_{i=1}^{n} X_{i} \sum_{i=1}^{n} Y_{i}}{\sqrt{\left[n \sum_{i=1}^{n} X_{i}^{2}-\left(\sum_{i=1}^{n} X_{i}\right)^{2}\right]\left[n \sum_{i=1}^{n} Y_{i}^{2}-\left(\sum_{i=1}^{n} Y_{i}\right)^{2}\right]}}
$$

The degree of association using correlation coefficient is defined in Table 1.

Table 1 - Coefficient correlation interpretation

\begin{tabular}{ccc}
\hline & Correlation Coefficient & Interpretation \\
\hline 1 & -1 & Perfect \\
0.9 & -0.9 & Very Strong \\
0.8 & -0.8 & Very Strong \\
0.7 & -0.7 & Moderate \\
0.6 & -0.6 & Moderate \\
0.5 & -0.5 & Fair \\
0.4 & -0.4 & Fair \\
0.3 & -0.3 & Fair \\
0.2 & -0.2 & Poor \\
0.1 & -0.1 & Poor \\
0 & 0 & None \\
\hline
\end{tabular}

The correlation between two variables is said to be significant when the significance of correlation test less than $\alpha=0.05$.

On the other hand, the effect of predictor variables to response variable was analyzing by using multiple linear regression. The model is depicted in equation (2):

$$
Y_{i}=\beta_{0}+\beta_{1} X_{1 i}+\beta_{2} X_{2 i}+\ldots+\beta_{p} X_{p i}+\varepsilon_{i} i=1,2, \ldots, n
$$

Where: $p=$ number of predictors; $n=$ sample size.

The significant effect of any predictor denoted by t-test where the significance result is lower than $\alpha=0.05$. 
There are several assumptions that are underlying multiple linier regression. They are normality, non-multicollinearity, non-autocorrelation, and non-heteroscedasticity. Firstly, Kolmogorov-Smirnov test was performed to check the normality assumption. Meanwhile, identification of multicollinearity based on variance inflation factors (VIF). Non-autocorrelation assumption was tested by using Durbin-Watson test. Lastly, non-heteroscedasticity assumption state can be obtained by performing Glejser test (Gujarati, 2004). The data analysis in this research was conducted using the help of statistical software namely SPSS version 25.

\section{RESULTS AND DISCUSSION}

Pearson correlation analysis results between income and each predictor variables are presented in Table 2.

Table 2 - Summary of Pearson Correlation Analysis

\begin{tabular}{cccc}
\hline Predictor & Pearson Correlation & Significance & Remark \\
\hline Farming area & 0.978 & 0.000 & Significant \\
Rope & 0.934 & 0.000 & Significant \\
Buoy & 0.827 & 0.000 & Significant \\
Wooden peg & 0.812 & 0.000 & Significant \\
Ballast & 0.864 & 0.000 & Significant \\
Boat & 0.338 & 0.218 & Non-significant \\
Seed & 0.970 & 0.000 & Significant \\
\hline
\end{tabular}

It can be seen from Table 1 that from all the predictors, there is a variable which has poor correlation on income which is cost of boat. It means that cost of boat has no association with farmers' income. Therefore, the variable is excluded from further analysis. In accordance with Limi et al (2018), any investment that related to boat has low depreciation cost compared to other production materials. Depreciation cost is a reduction cost of certain fixed asset over its full utilization (Lukic et al, 2016). Thus, the cost of boat may not greatly associate with farmers' income because the boat can be used for long time that involved numerous farming cycle. Meanwhile, other predictors have correlation coefficient greater that 0.80 , which indicate that those variables have very strong association with income.

Before performing the multiple linear regressions, assumption tests need to be checked first. Gujarati (2004) stated that assumption test in regression linear is important to guarantee the validation of regression results. The result of assumptions checking depicted in Table 3 .

Table 3 - Summary of multiple linear regression assumption checking

\begin{tabular}{llll}
\hline \multicolumn{1}{c}{ Assumption } & \multicolumn{1}{c}{ Method } & \multicolumn{1}{c}{ Result } & Remark \\
\hline Normality & Kolmogorov-Smirnov test & Sig. $=0.200$ & Normal \\
Non-multicollinearity & VIF & There are predictors which have VIF $>10$ & Multicollinear \\
Non-autocorrelation & Durbin-Watson test & $\mathrm{D}=1.810$ & No autocorrelation \\
& & $\mathrm{dL}=0.814 ; \mathrm{dU}=1.750$ & Homoscedasticity \\
Non-heteroscedasticity & Glejser test & Sig. $=0.052$ & \\
\hline
\end{tabular}

Based on assumption tests results in Table 3, only non-multicollinearity which is being violated. The handling action to overcome violation of non-multicollinearity by excluding the predictor variables who have VIF (Variance Inflation Factor) greater than 10 (farming area (X1) and cost of ballast (X5)). The rest variables are kept to be included in multiple linear regression analysis.

Table 4 - Multiple linear regression results

\begin{tabular}{ccccc}
\hline Term & Coefficient $(\beta)$ & T-statistics & Significance & Remark \\
\hline Constant & 4.91 & 4.27 & 0.001 & - \\
Rope & 0.596 & 4.35 & 0.001 & Significant \\
Buoy & 0.089 & 0.46 & 0.657 & Non-significant \\
Wooden peg & 0.144 & 0.75 & 0.471 & Non-significant \\
\hline
\end{tabular}


Table 4 presents that all of the predictors have positive coefficient regression which mean that the more rope's cost, buoy's cost and wooden peg are, the greater income of the farmer is. The estimated coefficient of rope suggests that if the cost of rope increases by $1 \%$, the farmers' income will rise by $0.596 \%$. Meanwhile, when the cost of buoy surges by $1 \%$, the farmers' income will grow by $0.089 \%$. Nonetheless, $1 \%$ of wooden peg cost increasing will result to larger income by $0.144 \%$.

The finding indicates that large investment in seaweed farming will result to high production which represents farmers' profit. A closer look on the table also revealed that the effect on income of rope's cost predominate other predictors since its estimated regression coefficient is the highest among them. It also supported by the significance results whereas the only variable that has significance less than $\alpha=0.05$ is rope's cost. Thus, it can be said that rope's cost has significant effect to the income of seaweed farmers, while the others have not. The outcome is highly probable due to the most dominant method used in Rote Ndao district for seaweed farming is long-line method which requires a lot of rope. The advantage of such method is cheaper but does not resist to the effect of wind and wave (Fausayana et al, 2018). As the consequence, a successful seaweed farming in Rote Ndao district is influenced by the number of rope that used by the farmer.

\section{CONCLUSION}

The preliminary analysis prior to multiple linear regression have been reduced some predictors. Consequently, three predictors left for multiple linear regression. All of those have positive influence to the income of seaweed farmers in Rote Ndao district, but only cost of rope significantly influences the farmers' income.

\section{SUPPLIED TABLES}

Table 1 - Coefficient correlation interpretation

\begin{tabular}{|c|c|c|}
\hline \multicolumn{2}{|c|}{ Correlation Coefficient } & Interpretation \\
\hline 1 & -1 & Perfect \\
\hline 0.9 & -0.9 & Very Strong \\
\hline 0.8 & -0.8 & Very Strong \\
\hline 0.7 & -0.7 & Moderate \\
\hline 0.6 & -0.6 & Moderate \\
\hline 0.5 & -0.5 & Fair \\
\hline 0.4 & -0.4 & Fair \\
\hline 0.3 & -0.3 & Fair \\
\hline 0.2 & -0.2 & Poor \\
\hline 0.1 & -0.1 & Poor \\
\hline 0 & 0 & None \\
\hline
\end{tabular}

Table 2 - Summary of Pearson Correlation Analysis

\begin{tabular}{cccc}
\hline Predictor & Pearson Correlation & P-value & Remark \\
\hline Farming area & 0.978 & 0.000 & Significant \\
Rope & 0.934 & 0.000 & Significant \\
Buoy & 0.827 & 0.000 & Significant \\
Wooden peg & 0.812 & 0.000 & Significant \\
Ballast & 0.864 & 0.000 & Significant \\
Boat & 0.338 & 0.218 & Non-significant \\
Seed & 0.970 & 0.000 & Significant \\
\hline
\end{tabular}

Table 3 - Summary of multiple linear regression assumption checking

\begin{tabular}{llll}
\hline \multicolumn{1}{c}{ Assumption } & \multicolumn{1}{c}{ Method } & \multicolumn{1}{c}{ Result } & Remark \\
\hline Normality & Kolmogorov-Smirnov test & Sig. $=0.200$ & Normal \\
Non-multicollinearity & VIF & There are predictors which have VIF $>10$ & Multicollinear \\
Non-autocorrelation & Durbin-Watson test & $\mathrm{D}=1.810$ & No autocorrelation \\
& & $\mathrm{dL}=0.814 ; \mathrm{dU}=1.750$ & Homoscedasticity \\
Non-heteroscedasticity & Glejser test & Sig. $=0.052$ & \\
\hline
\end{tabular}




\section{REFERENCES}

1. Andayani A, Pamungkas A. 2018.Identifikasi Potensi Kesesuaian Perairan untuk Budidaya Rumput Laut di Teluk Mulut Seribu, Rote Ndao, Nusa Tenggara Timur. Media Akuakultur. 13(2): 99-107.

2. Anderson DR, Sweeney DJ, Williams TA.2009.Statistics for Business and Economics. Thomson South-Western. Ohio.

3. BPS.2016.Perkembangan Ekspor Rumput Laut di Indonesia tahun 2012-2015. Badan Pusat Statistik. Jakarta.

4. BPS.2015.Volume Produksi Komoditas Unggulan Indonesia. Badan Pusat Statistik. Jakarta.

5. Chen KZ, Duan Y. Competitiveness of Canadian agri-food exports againts competitors in asia: 1980-971. 33. University of Alberta, 2001.

6. Fausayana I, Muhidin, Sidu D, Arimbawa P. 2018.Cultivation of seaweed Eucheuma cottonii on longline with Floating Inverted Mosquito Net Model. AACL Bioflux. 11(4): 1009-14.

7. Gujarati D.2004.Basic Econometrics. McGraw-Hill. London.

8. KKP.2015.Potensi dan Volume Produksi Rumput Laut Indonesia 2014. Kementerian Kelautan dan Perikanan. Jakarta.

9. Limi MA, Sara L, Ola TL, Yunus L, Suriana, Sitti A. Adha Taridala, et al. 2018.The production and income from seaweed farming after the sedimentation in Kendari Bay. AACL Bioflux. 11(6): 1927-36.

10. Lukic R, Hanic A, Hanic A. 2016. The Impact of Depreciation Expense on Performance of Trade in Serbia. International Review. 3(4): 123-37.

11. Parenrengi A, Sulaeman E, Suryati A, Tenriulo. 2006.Karakteristik Genetika Rumput Laut Kappaphycus alvarezii yang Dibudidayakan di Sulawesi Selatan. Jurnal Riset Akuakultur. 1(1): 1-11.

12. Radiarta I, Erlania, Haryadi J, Rosdiana A. 2016.Analisis pengembangan budidaya rumput laut di Pulau Sebatik, Kabupaten Nunukan, Kalimantan Utara. Jurnal Kebijakan Perikanan Indonesia. 8(1): 29-40.

13. Soejarwo PA, Yusuf R. 2018.Saluran pemasaran rumput laut (Euchema cottonii) di Sumba Timur, Nusa Tenggara Timur. Buletin IImiah "MARINA" Sosial Ekonomi Kelautan dan Perikanan. 4(2): 45-51. 